\title{
Episodic sediment delivery and landscape connectivity in the Mancos Shale badlands and Fremont River system, Utah, USA
}

\author{
Andrew E. Godfrey ${ }^{1}$, Benjamin L. Everitt ${ }^{\mathrm{a}}$, José F. Martín Duque ${ }^{\mathrm{b}, *}$ \\ a 170 W. 300 North, Ivins, Utah 84738 , USA \\ ${ }^{b}$ Department of Geodynamics, Complutense University, 28040 Madrid, Spain
}

Keywords:

Mancos Shale badlands

Erosion

Mass movement

Connectivity

Coupling

Arroyo cutting

\begin{abstract}
A B S T R A C T
The Fremont River drains about $1000 \mathrm{~km}^{2}$ of Mancos Shale badlands, which provide a large percentage of the total sediment load of its middle and lower reaches. Factors controlling sediment movement include: weathering that produces thin paralithic soils, mass movement events that move the soil onto locations susceptible to fluvial transport, intense precipitation events that move the sediment along rills and across local pediments, and finally Fremont River floods that move the sediment to the main-stem Colorado River. A forty-year erosion-pin study has shown that down-slope creep moves the weathered shale crust an average of $5.9 \mathrm{~cm} / \mathrm{yr}$. Weather records and our monitoring show that wet winters add large slab failures and mudflows. Recent sediment-trap studies show that about $95 \%$ of sediment movement across pediments is accomplished by high-intensity summer convective storms. Between 1890 and 1910, a series of large autumn floods swept down the Fremont River, eroding its floodplain and transforming it from a narrow and meandering channel to a broad, braided one. Beginning about 1940, the Fremont's channel began to narrow. Sequential aerial photos and cross-sections suggest that floodplain construction since about 1966 has stored about 4000 to $8000 \mathrm{~m}^{3}$ of sediment per kilometer per year. These data suggest that it will take two centuries to restore the floodplain to its pre- 1890 condition, which is in line with geologic studies elsewhere on the Colorado Plateau.

The various landscape elements of slope, pediment, and floodplain are semi-independent actors in sediment delivery, each with its own style. Accelerated mass movement on the slopes has an approximate 20-year recurrence. Sediment movement from slope across pediments to master stream is episodic and recurs more frequently. The slope-to-pediment portion of the system appears well connected. However, sediment transport through the floodplain is not well connected in the decadal time scale, but increases in the century and millennial time scales, and changes over time depending on the cvcle of arrovo cutting and filling.
\end{abstract}

\section{Introduction}

This paper explores the concept of coupling, defined as the degree of landscape connectivity in an arid region of the southwest United States, where erosional and transportational processes operate at various time scales. In describing landscape dynamics, the term 'connectivity' describes the transmission of matter and energy among system components (Harvey 1987, 1997, 2001, 2002). This study combines previously published work, on-going studies, and recent monitoring conducted for the US Bureau of Iand Management (BLM).

The study site in the Caineville Mesas, Factory Butte area of southcentral Utah (Fig. 1), contains outstanding badland topography

\footnotetext{
* Corresponding author. Dpto. de Geodinámica, Facultad de Ciencias Geológicas, Universidad Complutense de Madrid, 28040 Madrid, Spain. Tel.: +34 913944720 ; fax: +34913944845 .

E-mail addresses: agodfrey39@mindspring.com (A.E. Godfrey),

rockdoc@xmission.com (B.L. Everitt), josefco@geo.ucm.es (J.F. Martín Duque).

1 Deceased.
}

(Stokes 1986, p. 221). This area is an excellent place to study processes, rates, and interrelationships of erosional processes on badland slopes (see Howard, 1994) because of several factors: first, the shales within the badlands are nearly homogenous with only a few thin sandstone beds; second, there is little coarse sediment from external sources within the badlands to complicate the erosional processes; and third, the area of badlands is nearly devoid of vegetation, while there is vegetation along the floodplain of the Fremont River. Finally, several studies have been carried out on individual portions of the system that can be integrated to gain an understanding of their connectivity (Harvey, 2002).

\section{Regional setting}

\subsection{Geology}

The study area is underlain by three members of the Mancos Shale Formation. From the base upward they are: the Tununk Shale Member, approximately 195 m thick; the Ferron Sandstone Member, 


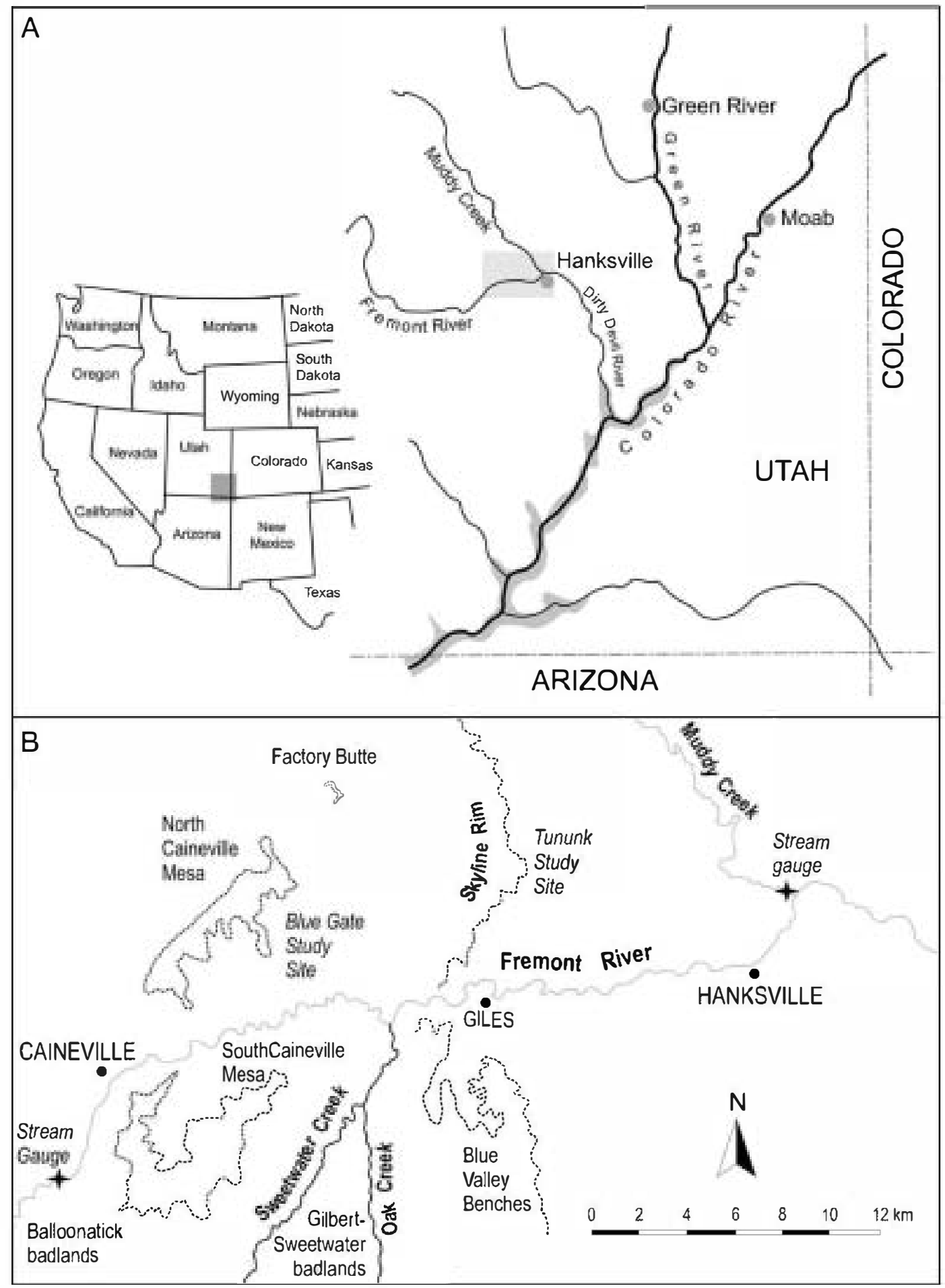

Fig. 1. A) The southeastern portion of Utah showing the location of the study area and the relation of the Fremont River to the main-stem Colorado River. B) Study area.

approximately $75 \mathrm{~m}$ thick; and the Blue Gate Shale Member, approximately $430 \mathrm{~m}$ thick. This area is located on the east limb of the broad, gently-dipping Henry Mountains syncline, thus the outcrop pattern runs in a general north-south direction. These units are overlain by east-west trending bands of gravel-capped benches and fine-grained floodplain alluvium adjacent to the east-flowing Fremont River.

Both shale units of the Mancos Formation are described as offshore marine deposits (Patterson et al., 1985). The Tununk "consists of dark-gray, fissile shale containing a few thin layers of bentonite near the base and top and a few thin, calcareous and shaley sandstone layers near the middle." (Hunt et al., 1953, p. 79) "The Blue Gate Shale Member... lithologically resembles the Tununk Shale Member of the Mancos in being composed almost wholly of dark-gray, finely laminated marine shale. The shale includes some very thin beds of bentonite, shaley sandstone, or shaley limestone. The lower twothirds of the member is almost homogeneous, laminated shale except for a few slightly sandy or calcareous layers." (Hunt et al., 1953, p. 8384). Erosional studies reported below are located in this lower portion of the Blue Gate Member. Hepworth (1965, p. 130) reported that the 
"particles of the shale are mostly silt sized and are weakly cemented with calcite, dolomite, and minor amounts of gypsum and clay. Quartz is the dominant mineral in all fractions (75-80\%). Clay minerals are not abundant, but in places illite and monmorillonite make up $10 \%$ to $15 \%$ of the shale." Richard Grauch (pers. comm., 2005) reports that there is about $12 \%$ more non-clay minerals in the Tununk soils than in the Blue Gate soils.

\subsection{Climate}

The climate in the study area is arid-continental in that both temperature and precipitation are highly variable (Western Regional Climate Center). The Hanksville weather station, located about $20 \mathrm{~km}$ east of the study area at an elevation of $1310 \mathrm{~m}$, has been operated continuously since 1948, giving 58 years of record. Based upon information from this station, the average annual temperature is $12{ }^{\circ} \mathrm{C}$; however, recorded temperatures have reached a high of $46{ }^{\circ} \mathrm{C}$ and a low of $-36^{\circ} \mathrm{C}$. Daily temperature variations of $20^{\circ} \mathrm{C}$ are common. The frost-free period averages about 182 days. The mean daily high temperature in the winter is $7{ }^{\circ} \mathrm{C}$ while that of the summer is $35^{\circ} \mathrm{C}$. Because of high daytime temperatures and very low relative humidity. evaporation rates are high.

Annual precipitation averages $140 \mathrm{~mm}$, but has ranged from a high of $248 \mathrm{~mm}$ in 1957 to a low of $34 \mathrm{~mm}$ in 1956, a range of 728\%. This high variability is also reflected in the monthly data, from a high month of $90.9 \mathrm{~mm}$ to many months of no precipitation. The closest other weather stations with over 50 years of record are at Green River, $83 \mathrm{~km}$ away, and Moab, $100 \mathrm{~km}$ distant. Both stations have recorded a similar variation in precipitation.

Two distinct weather patterns provide moisture to the region (Fig. 2; Peterson 1994, pp. 36-38). Frontal rain and snow storms from the Pacific Northwest cover broad areas during the winter period of November through May. These storms tend to be low intensity and moderate to long duration. Rare snowfalls of as much as $43 \mathrm{~cm}$ have been recorded at Hanksville.

Starting about the middle of July a southern monsoonal pattern generates localized convective storms of short duration but high magnitude. Nearly half (47\%) of the average annual precipitation occurs in this July through October period (Fig. 2). The summer monsoon grades into the winter regime with an occasional large storm of long duration in September or October. These auturnn storms are responsible for the greatest recorded rainfalls.

Hereford and Webb (1992) have documented decadal-scale changes in the frequency and duration of summer rainfall in the southern Colorado Plateau during the last century. In particular, 1940 marked a decrease in summer precipitation, which may have influenced the ratio of mass movement to fluvial erosion, and hence the connectivity of landscape elements described here.

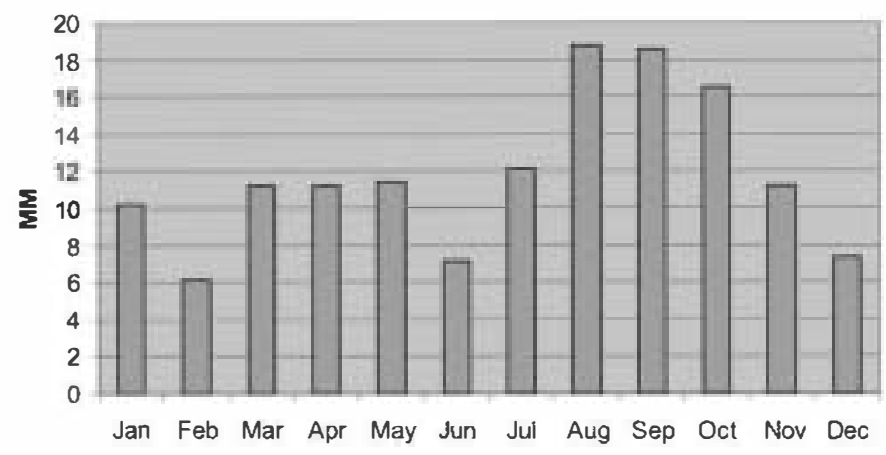

Fig. 2. Average monthly precipitation recorded at the Hanksville weather station. The period of record is 1948 to 2005. Note the increased precipitation in August, September, and October.

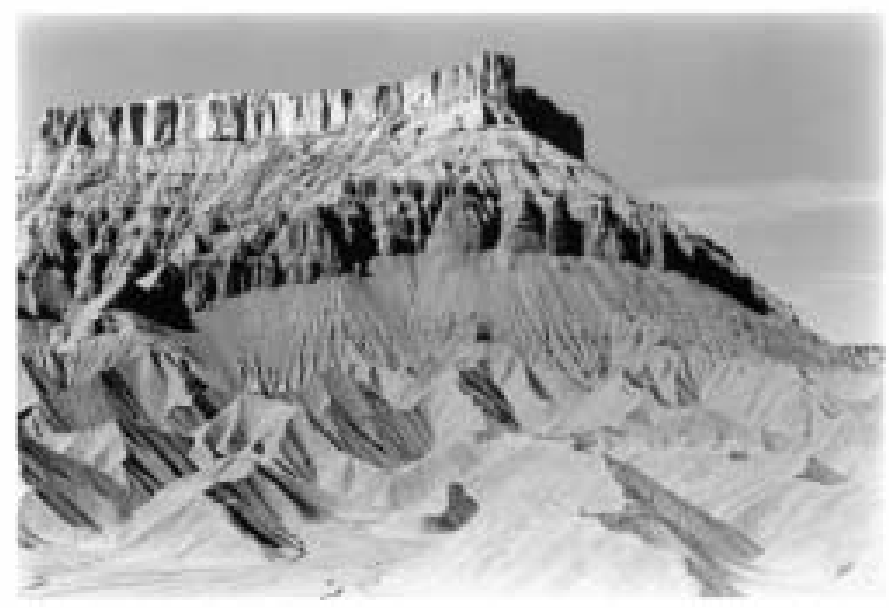

Fig. 3. General view of Blue Gate Shale badlands with North Caineville Mesa in the background. The sharp-crested ridges are separated by pediments that widen as they move away from the mesa.

\subsection{Landfonns}

The study area encompasses $1000 \mathrm{~km}^{2}$ underlain by the Mancos Shale Formation in the middle reach of the Fremont River. The uplands consist mostly of intricately eroded badlands on the gray shale units of the Mancos Formation, with a few mesas and hogbacks formed by the more resistant sandstone units.

The dominant landforms of the badlands underlain by the Blue Gate Shale are narrow, sharp-crested ridges up to $1 \mathrm{~km}$ in length with straight side-slopes (Fig. 3). These side-slopes are inclined at approximately $40^{\circ}$ when they are a minimum of $30 \mathrm{~m}$ long (Fig. 4). In a few areas, these slopes become vertical cliffs that are explained as caused by stream or undercutting or by wind erosion (Godfrey, 1997a). Where the slopes are less that $30 \mathrm{~m}$ long, near the distal ends of the ridges, their inclination decreases until they become gently-rounded mounds.

Theoutcrop of the Tununk Shale Member is different from that of the Blue Gate. Throughout most of its area "it forms an asymmetric [strike] valley. One side of the valley is steep rising to an escarpment, generally up toc. $100 \mathrm{~m}$ high, capped by the Ferron Sandstone Member; the other side is much less steep and much lower." (Hunt et al., 1953, p. 80) The

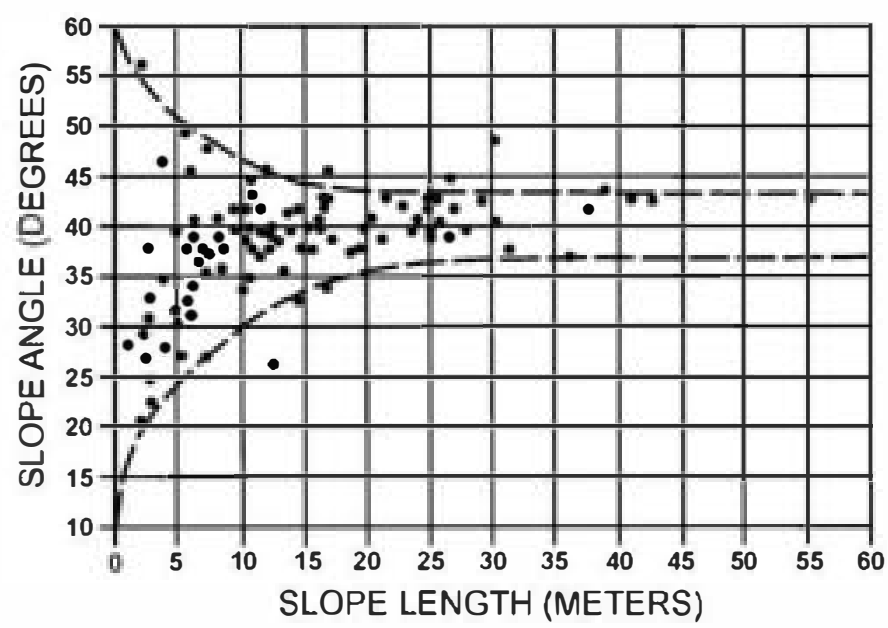

Fig. 4. Graph of measurements of slope angle versus slope length in the Blue Gate Shale Lines were added manually for easier interpretation. 


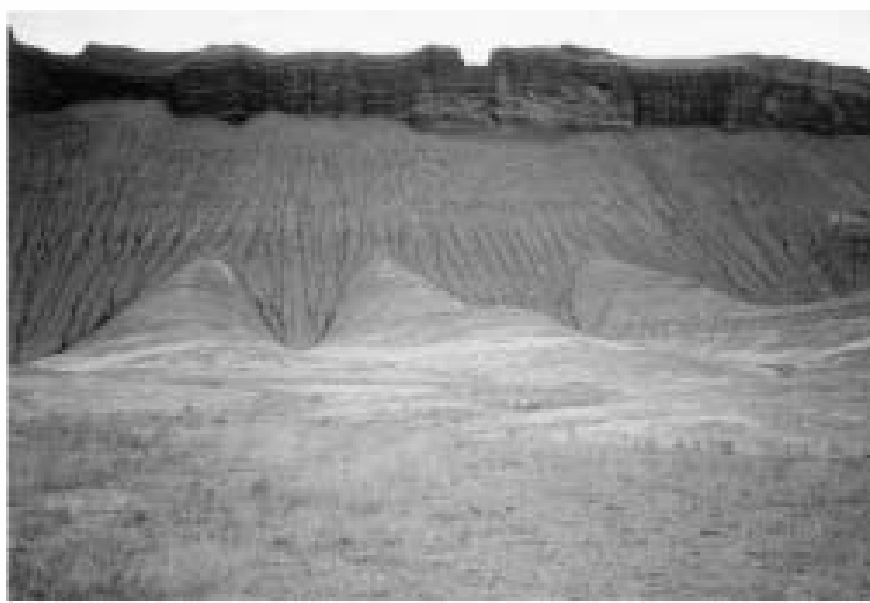

Fig. 5. Outcrop of the upper portion of the Tununk Shale below the Skyline Rim showing the short, rounded ridges extending out from the rim. Note the deep rilling.

valley bottom is gently rolling lowland cut by a few washes. The scarps leading down from the sandstone cap are slightly scalloped with areas of divergent flow extending only 20 to $30 \mathrm{~m}$ out from the rim as gently rounded knolls. The badland ridges characteristic of the Blue Gate are generally missing in the Tununk (Fig. 5).

Fringing the uplands-and separated from them by a prominent break in slope-is an apron of gently sloping pediment bearing thin silty soil over weathered shale. Pediments are crossed by first and second-order rills. As these rills coalesce downstream into washes and gullies, the pediment apron grades into an alluvial plain underlain by silty alluvium of increasing thickness toward the Fremont River.
The valley of the Fremont River itself is underlain by up to $30 \mathrm{~m}$ of alluvium. Gray silt locally derived from the Mancos Shale is interbedded with sand and gravel from more distant sources upstream. Two prominent surfaces are evident in the valley. The active floodplain is 2 to $3 \mathrm{~m}$ above the riverbed, and the older floodplain abandoned by arroyo cutting lies 4 to $5 \mathrm{~m}$ above the river. Large tributary drainages are graded to the active floodplain, while small drainages may still be graded to the abandoned floodplain.

\subsection{Soils}

Soils developed on the slopes are thin and paralithic (Fig. 6), with a three-layer structure. The surface is a crust, 0.8 to $2.25 \mathrm{~cm}$ thick, with a popcorn texture (Hodges and Bryan, 1982), and is formed by silt-sized shale chips cemented by soluble salts. When the crust is removed, it can be reformed in one wetting-and-drying cycle. Desiccation has cracked this crust into polygons averaging $6 \mathrm{~cm}$ across. Crescentshaped cracks, concave down-slope and ranging from 20 to $100 \mathrm{~cm}$ in width, are also present in places.

On slopes formed on Blue Gate Shale, a layer, 0 to $24 \mathrm{~cm}$ thick, of randomly-oriented silt-to-sand-sized shale chips is present next below the crust. The chips are flat and longer than they are wide. In places, the upper portion of this layer is loosely cemented by soluble salts. This cemented portion generally thickens in the down-slope direction from 1 to $2 \mathrm{~cm}$ near the slope crest, and 4 to $8 \mathrm{~cm}$ near the slope toe. The lower portion of this slope is not cemented and increases in thickness from 0.5 to $2 \mathrm{~cm}$ near the crest, and 4 to $19 \mathrm{~cm}$ near the slopetoe. In places, there is a gradation with depth as the chips become larger and more horizontally oriented. This layer also increases in thickness in the down-slope direction from $4 \mathrm{~cm}$ near the top to $8 \mathrm{~cm}$ near the base. Variations in the thickness of this layer in the mid-slope

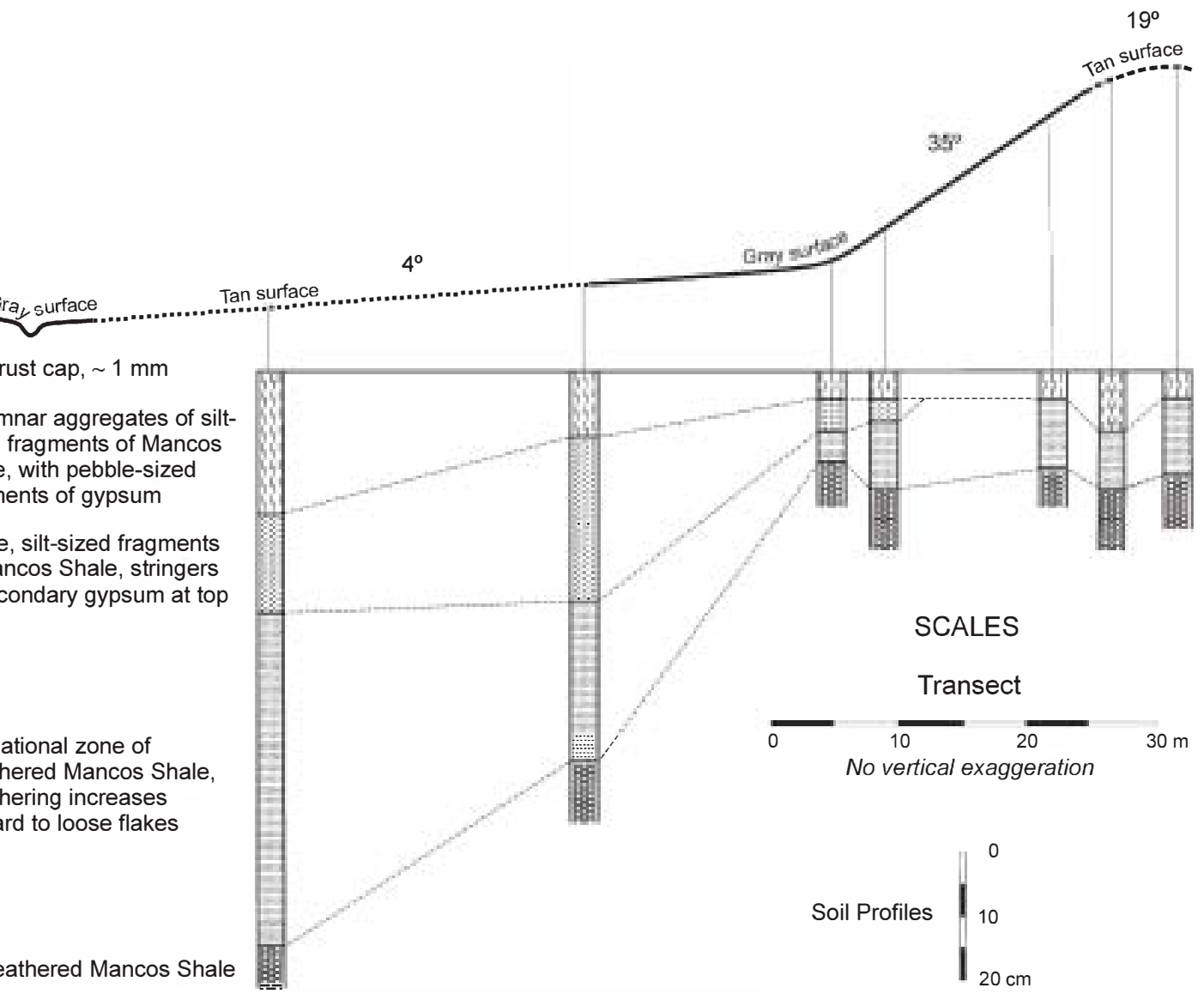

Fig. 6. Soil transect down a ridge of Blue Gate Shale, near the North Caineville Mesa (see Fig. 1). 


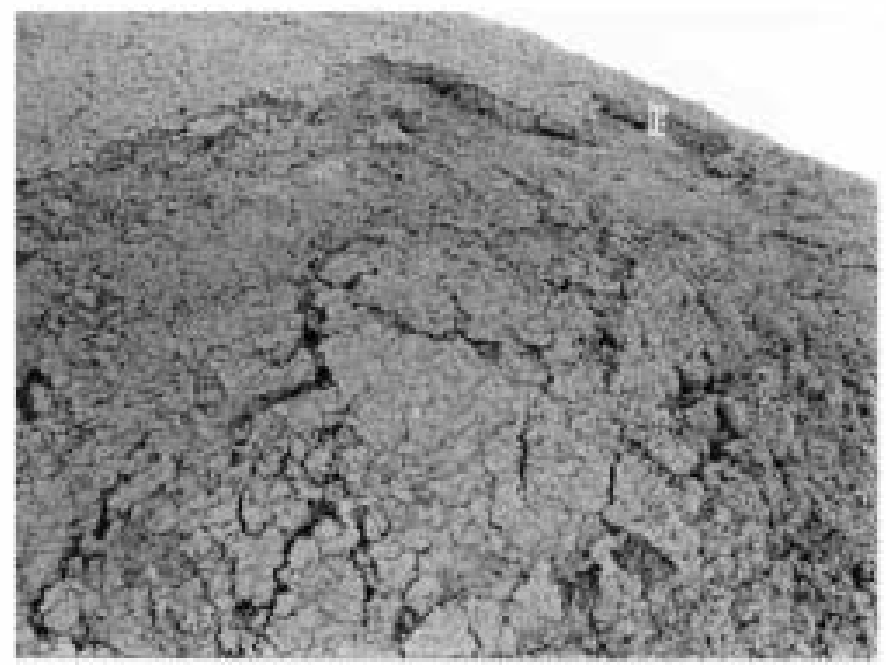

Fig. 7. Photograph of a small-slab failure. The 17-cm scale in the upper right shows size of failure and thickness of crust.

area appear to be caused by slab failures and flows. It can be absent from detachment areas and doubly thick where movement halted.

The layer of randomly-oriented chips grades into a lower layer, generally less that $10 \mathrm{~cm}$ thick, that is horizontally oriented. Chip size increases with depth and grades into unweathered rock with an indefinite boundary.

Steep slopes underlain by the Tununk Shale appear to have about the same soil profile as those underlain by the Blue Gate. However, in the valley bottoms "... where the shale surface is gently undulating weathering yields a foot or more of fluffy aggregate composed of tiny flakes of shale, bits of clay and particles of sand. This soil, if it can be called soil, is easily moved about by the wind and locally collects in small dunes. This soil is not confined to the obviously bentonitic zones and its peculiar behavior may reflect the presence of other unusual constituents." (Hunt et al., 1953, p. 80).

\section{Erosion processes}

\subsection{Mass movement}

Three processes generate mass movement on the Blue Gate Shale slopes: creep, slab failure, and mudflow. All three of these processes move sediment to the base of the slopes, where it awaits fluvial transport out of the system. While all are gravity driven, they operate at different frequencies and have different controls.

\subsubsection{Creep}

A forty-year study (Godfrey, 1997b) of the downslope creep movement of surface crust was carried out by placing 20 pins along the contour between two benchmarks and then measuring the downslope movement of each pin through time, along the slope to the point where the pin entered the soil. The results indicated a rate of $5.9 \mathrm{~cm}$ per year of down-slope creep movement for measurements taken near the mid-slope position and where the slope was only shale. Adjacent pins often moved together, while non-adjacent pins in the line moved differing amounts. This resulted in an increase in standard deviation with time. Annual downslope movement was not uniform, but was greater in years such as 1985 and 1989 when the crust remained wet during several consecutive days of precipitation.

\subsubsection{Slab failure}

At places along the Blue Gate Shale slopes, concave downward tension cracks are evident. Some are only a centimeter or so wide, while others are much larger. These cracks are detachment scarps at the heads of slabs of the crust, and some underlying material that slipped down-slope. Fig. 7 shows an example of one that moved about a meter. Small-slab failures (Fig. 7) can account for the variation in soil thickness: thin in the head-scar region and a doubling of the thickness where the slab comes to rest. Although there are no observations correlating these small-slab failures with precipitation events, it is apparent that the movement of these slabs occurs at those times when the component of weight parallel to the slope exceeds the frictional resistance with the underlying layer. Such weight increase is most likely due to short-term loading by the additional weight of absorbed precipitation.

The amount of water and the duration of the wetted condition both appear to be important in causing mass movement such as slab failure. It appears that several days of continuous wetting produce episodic increases in the rate of movement (Godfrey, 1997b, p. 191). Observation of precipitation events during the wet winters of 1997 and 2005 strengthen this proposition.

In January 1997, $33 \mathrm{~cm}$ of snow fell in the study area with a water content of $42.7 \mathrm{~mm}$ as measured at the Hanksville weather station. Due to cold weather, the snow remained on the ground for 26 days, releasing water to the ground by melting for 10 of those 26 days. The result was that many of the hillsides were stripped down to near bedrock with the sediment accumulating at the base of the slopes (Fig. 8).

\subsubsection{Mudflow}

The wet winter of 2005 resulted in mudflows, the third type of mass movement. In that year, January received $36.6 \mathrm{~mm}$ of rain and snow. The result was a series of mudflows (Fig. 9) that initiated about mid-slope. The flows did not strip the soil down to bedrock and there was no obvious bedrock control; they were not restricted to areas of convergent flow. As with the large-slab failures, these flows carried sediment only to the toe slope position, not out to the Fremont River.

The January monthly precipitation totals that caused both the largeslab failure and the mudflows were each about four times the average for January (420\% in 1997 and 350\% in 2005). While the monthly totals were quite similar, the daily delivery of moisture to the soil was different (Fig. 10). The 1997 snowmelt delivered small and nearly equal amounts on a nearly continuous basis. The 2005 rain and wet snow event was marked by two days of high precipitation followed by several days of lesser amounts. It is possible that the first day's high precipitation (day 1 in Fig. 10) thoroughly soaked the soil, and the subsequent event (days 6,7 and 8) triggered the mudflows.

To summarize, erosion on shale slopes is dominated by mass movement. These processes move sediment to the toe slope position of the narrow ridges underlain by the Blue Gate Shale. Sixty-five

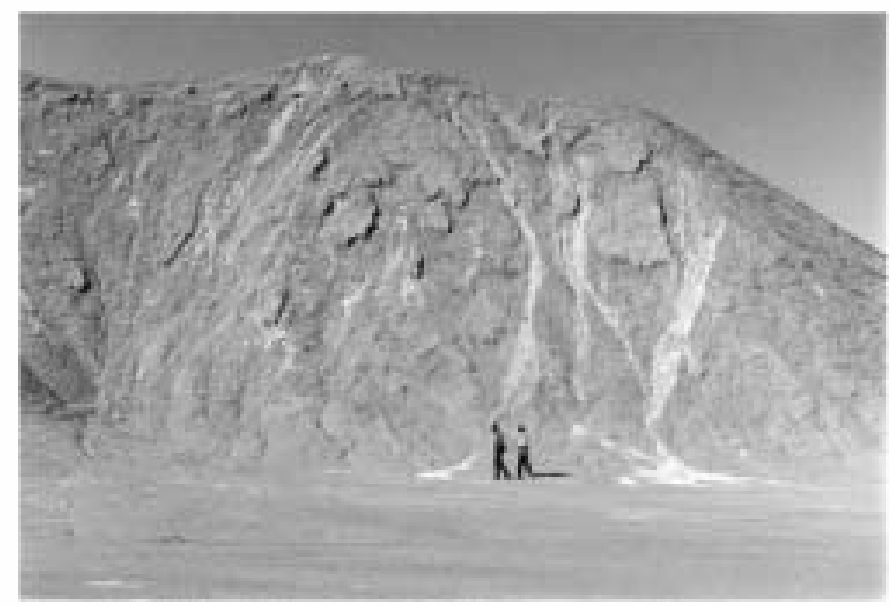

Fig. 8. Photograph of large-scale slab failure caused by slow melting of the winter 1997 snowstorm. Mudflows are also noticeable. 


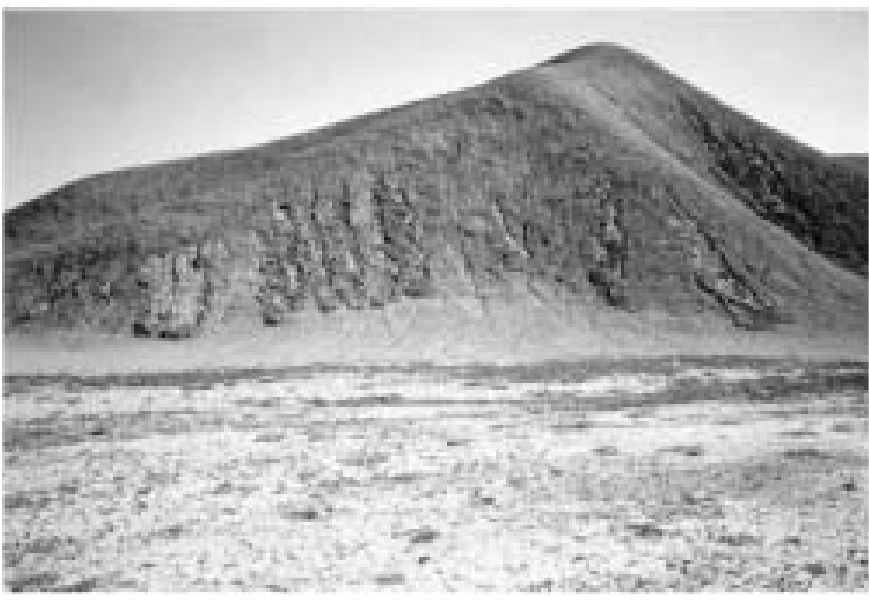

Fig. 9. Photograph of mudflows off the Blue Gate Shale ridges. Note that they start at several levels of the slope and in several topographic positions, but do not extend beyond the toe-slope position.

percent of creep movement occurs in the months of November through May. The large-slab failures and the mudflows can also occur during the same winter period and increase the percentage of downslope movement during these months. During the winter season, a combination of long-duration precipitation events and cool soil temperatures permit moisture to remain in the soil, leading to the mass movements. During the summer season, on the other hand, precipitation events, while intense, are of short duration, measured in terms of minutes or hours. Further, a recording soil temperature probe has frequently recorded temperatures in excess of $40^{\circ} \mathrm{C}$ and as much as $50{ }^{\circ} \mathrm{C}$. These hot conditions lead to rapid drying of the soil.

Slopes underlain by the Tununk Shale show no apparent signs of mass movement. There are no visible concave down-slope tension cracks. There were neither slab failures nor mudflows during the winters when these features appeared on the Blue Gate Shale slopes.

\subsection{Fluvial transport}

Fluvial processes occur mainly during the summer monsoon season or early fall when cut-off low pressure systems wander up from the south. These storm events can be of sufficient intensity, duration, and quantity to produce runoff that can transport the sediment to the Fremont River. Collection pits 0.9 by 2.4 by $3.7 \mathrm{~m}$ were installed adjacent to the toe-slope areas in both the Tununk and Blue Gate Shales at the request of the US Bureau of Land Management (BLM) for an on-going monitoring program. Sediment accumulation in these pits was measured from 2000 through 2005 generally in May and November. A comparison of the two sets of measurements

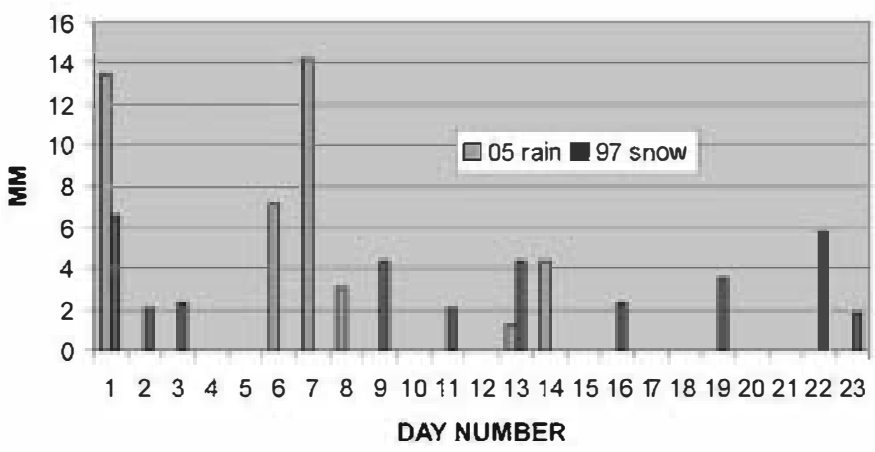

Fig. 10. Graphs of soil wetting events that led to slab failures (1997) and mudflows (2005). Arbitrary day numbers were assigned to align the two moisture-producing events.
Table 1

Rates of ground lowering calculated from sediment trapped in measurement pits near Caineville

\begin{tabular}{lcllll}
\hline Pit & $\begin{array}{l}\text { Sediment } \\
\text { volume } \mathrm{m}^{3}\end{array}$ & Drainage area ha & Years & $\mathrm{m}^{3} / \mathrm{ha} / \mathrm{yr}$ & $\begin{array}{l}\text { Ground lowering } \\
\mathrm{mm} / \mathrm{yr}\end{array}$ \\
\hline Blue Gate 1 & 13.33 & 0.1182 & 4.0 & 28.2 & 2.8 \\
Blue Gate 2 & 8.69 & 0.0648 & 4.0 & 33.6 & 3.5 \\
Tununk 1 & 14.64 & 0.0445 & 3.9 & 85.0 & 8.5 \\
Tununk 2 & 10.06 & 0.0567 & 3.9 & 45.8 & 4.6 \\
\hline
\end{tabular}

showed that $95 \%$ of the sediment carried off the slopes and onto the pediments occurred during the summer season. Further, the measurements indicated that fluvial erosion of the Tununk Shale is at about twice the rate of the Blue Gate Shale.

On the slopes, summer events have cut numerous rills (Fig. 11). These rills can persist for several years because a general lack of soil moisture during most winters hinders ice crystal formation even though freezing temperatures are common in the winter. Ice crystal growth can accelerate creep and loosening of the soil surface, which can lead to filling in of rills (Schumm and Lusby 1963, p. 3660-3661).

These summer storms produce short-duration flash floods in the narrow channels upstream from the pediments (Dick et al., 1997). However, out on the pediments, the flows spread out to produce sheet floods, as indicated by the presence of mud-balls (Goudie, 2004) and sandstone blocks on the flats between channels. A 40-year measurement of the bed of one dry wash near the proximal end of a pediment in the Gilbert Badlands area has shown that for the first 20 years (1966 to 1986) there was about $84 \mathrm{~cm}$ of aggradation. Then, from 1986 to 1994, the bed remained stable before downcutting $10 \mathrm{~cm}$ by 2006 . During that same 40 years, the channel meander remained in place until 1986 and then began to migrate outward a total of $25 \mathrm{~cm}$ from 1986 to 2006.

Suspended sediment transport by the Fremont River was investigated by reviewing the US Geologic Survey's records at the stream gauge station, Fremont River near Caineville. The USGS collected 87 suspended sediment samples at approximately once-amonth intervals from early 1967 to mid-1982. These data show almost no relationship between concentration of sediment and flow volume, suggesting that the river can transport most of the sediment supplied to it. Deposition occurs on the floodplain when the river overtops its banks because flow is slowed by roughness and vegetation.

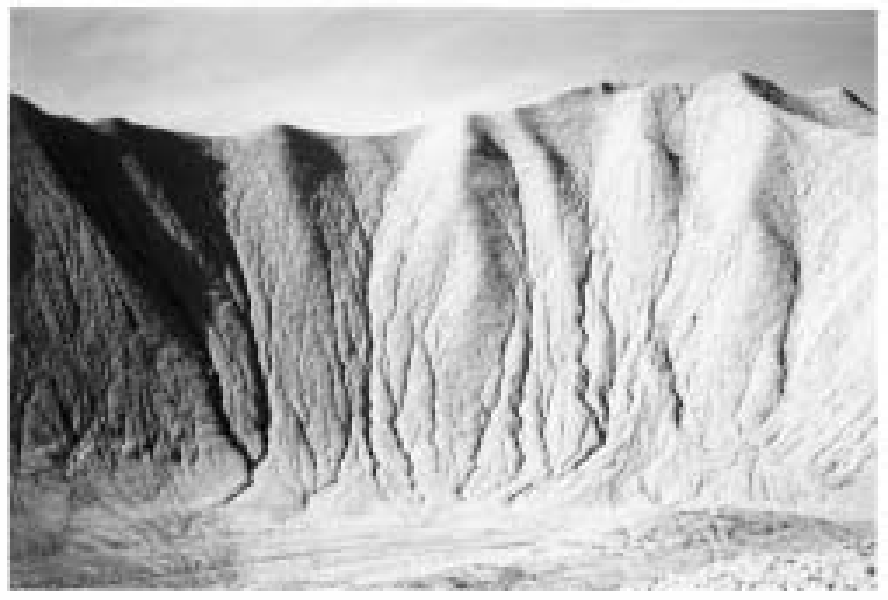

Fig. 11. A rilled Blue Gate Shale slope near Caineville, Utah, to show its summer morphology. 


\section{Rates}

\subsection{Return intervals}

To determine the return intervals of the large mass-movement events, such as the 1997 slab failures and the 2005 mudflows, winter months with over $30 \mathrm{~mm}$ of precipitation were selected. Then the daily amounts for each of these months were graphed and compared with the precipitation events of 1997 and 2005. The 2005 amounts were obtained from the Hanksville weather station, and the 1997 moisture delivered to the soil was computed by multiplying the percent of the reported daily change in snow depth by the reported water content of the original snow column, considering an equal distribution of water throughout that column. Only another winter precipitation event similar to the 1997 one that produced the large-slab failures, and only two events similar to the 2005 precipitation pattern that produced mud flows were found. This suggests that events capable of generating large-slab failures have a 30-year recurrence interval, while those capable of generating mudflows appear to have a 20 -year recurrence interval.

Estimating the return interval for fluvial transport of sediment from the slopes to the Fremont River has proven more difficult than determining mass-movement return intervals. This is because of several factors. First, the summer storms are quite localized, so that one that produces runoff sufficient to transport sediment in the Caineville area probably would not be reported at the Hanksville weather station. The second is that we do not know exactly the minimum magnitude and duration that is required to transport Mancos sediment. Now that a recording rain gauge has been installed at one of the study sites, we hope to get a better understanding of the size of summer storm necessary to produce sediment-transporting runoff. For now, our best estimate, from reviewing the Hanksville weather records reported by the Western Regional Climate Center, is that these storms have a 10 to $20 \%$ chance of occurring during a summer monsoon season.

\subsection{Rate of surface lowering on slopes}

Measurements indicate that the slope surfaces are lowering rapidly. Erosion pins were placed in the Gilbert Badlands area about $9 \mathrm{~km}$ south of the North Caineville Mesa sites, in 1966. They have been remeasured periodically since then (Godfrey 1979) with the most recent measurement in 2006. Pins were installed vertically and all measurements were in the vertical direction. Pins in the midslope position indicate a lowering rate of $3.2 \mathrm{~mm} / \mathrm{yr}$, while those in the toe slope position indicate a rate of $1.2 \mathrm{~mm} / \mathrm{yr}$.

A second set of data in the Caineville area resulted from measuring the lowering of the benchmarks at either end of the mass movement lines described above. The measured vertical lowering of slopes at these 11 locations over about 20 years ranges from 0 to $8.4 \mathrm{~mm} / \mathrm{yr}$. The result of these measurements is a $3.5 \mathrm{~mm} /$ $\mathrm{yr}$ average. There were some locations of rising, rather than lowering, but inspection showed that these areas were at the toes of recent mud flows or small slab failures where aggradation would be expected.

Theses rates of ground lowering are in agreement with the information from the sediment collection pit data (Table 1). These data indicate that the Blue Gate slopes are lowering between 2.8 to $3.5 \mathrm{~mm} / \mathrm{yr}$ while the Tununk slopes are lowering between 4.6 and $8.5 \mathrm{~mm} / \mathrm{yr}$, or at about twice the rate of the Blue Gate. This calculated rate for the Blue Gate slopes is in line with the amount of ground lowering at various benchmarks described above. This measured rate of ground lowering is also consistent with calculated amounts of slope retreat from terraces reported as Pinedale age (Last Glacial Maximum, LGM), ranging from 17 to 21 ka (Repka et al., 1997a, p. 71, 1997b).

\subsection{Rate of surface lowering on pediments}

Pins were placed on pediments in two portions of the Gilbert Badlands in 1966 and remeasured in 2006. These measurements used the same method as the slope measurements. One area showed aggradation of the pediment surface of $0.36 \mathrm{~mm} / \mathrm{yr}$, while the other showed erosion of $0.06 \mathrm{~mm} / \mathrm{yr}$. These observations suggest a relatively stable pediment surface.

Several lines of circumstantial evidence also suggest that the pediment surfaces are not being significantly eroded at present. In 1938, a series of survey stakes was placed along a pediment and adjacent slope to observe changes in rills. When revisited in 1968 (Hunt, 1973), many of the surveystakes on the pediment were present, while none were present on the adjacent side slopes. A repeat visit in 2006 confirmed the presence of survey stakes on the pediment. While the distance these stakes were set in the ground was not quantified, they did appear to be at about what one would expect. The same situation is true for a US Coast and Geodetic Survey benchmark set in 1927. Observation of the benchmark in 2005 suggests there has been no significant ground lowering in the ensuing 78 years.

A final line of evidence comes from a small purple flower, brittle phacelia (Phacelia demissa var. demissa). This 4 to $8 \mathrm{~cm}$ high flower carpeted the pediments in the Caineville area in the spring of 2005. It was totally absent from the slope areas. The seeds are between 2 and $4 \mathrm{~mm}$ long and are dispersed by water and wind. They can remain dormant for manyyears. This plant germinates only after a wet winter, and it has been reported that the last previous flowering was about 15 years before. If the pediments were actively aggrading or eroding, the seeds of this plant would be either buried or removed in the years between flowerings.

The pediments underlain by the Blue Gate Shale are prone to sheet flooding. This is indicated by the presence of locally derived mudballs and sandstone cobbles derived from the overlying Emery Sandstone caprock. Sandstone cobbles lying on the flat pediments indicate that flooded washes can overtop their banks and spread out onto the pediments. Sheet flooding can also be augmented by precipitation directly on the pediments. However, the finding that the pediment surface is neither aggrading nor eroding suggests that sheet flooding does not erode the pediments. This conclusion is in agreement with Smith (1958, p. 998) who concluded, "Sheet wash is apparently not a major erosional agency on the surface of miniature pediments once the surface has been developed, but is chiefly an agent of transportation and maintains the graded profile of the pediment by removing

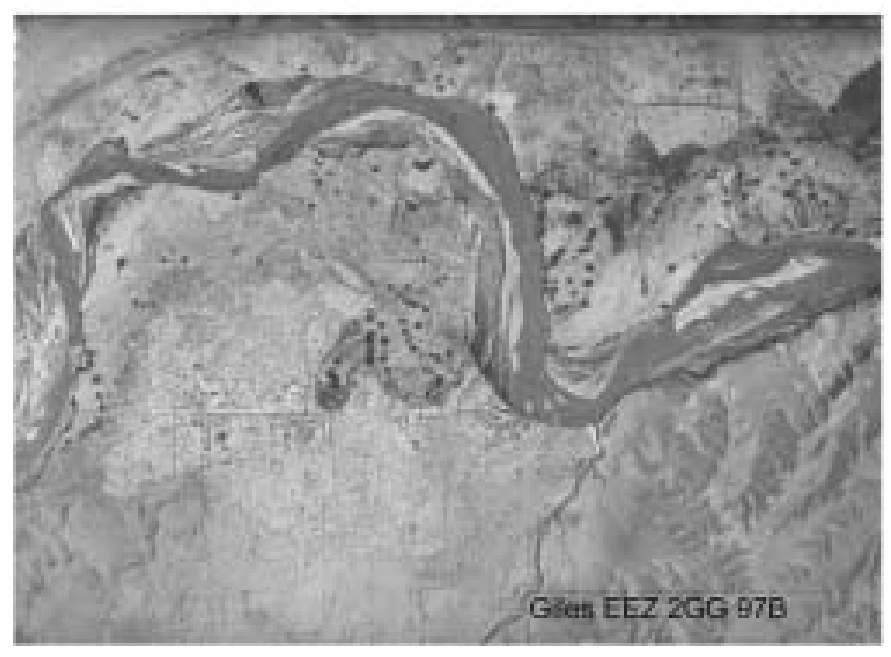

Fig. 12. 1966 aerial photograph of the site of the old town of Giles. The active river channel is about $150 \mathrm{~m}$ wide, the eroded flood channel is about $300 \mathrm{~m}$ wide, and nested oxbows of the pre- 1897 river are 15 to $30 \mathrm{~m}$ wide. 
A

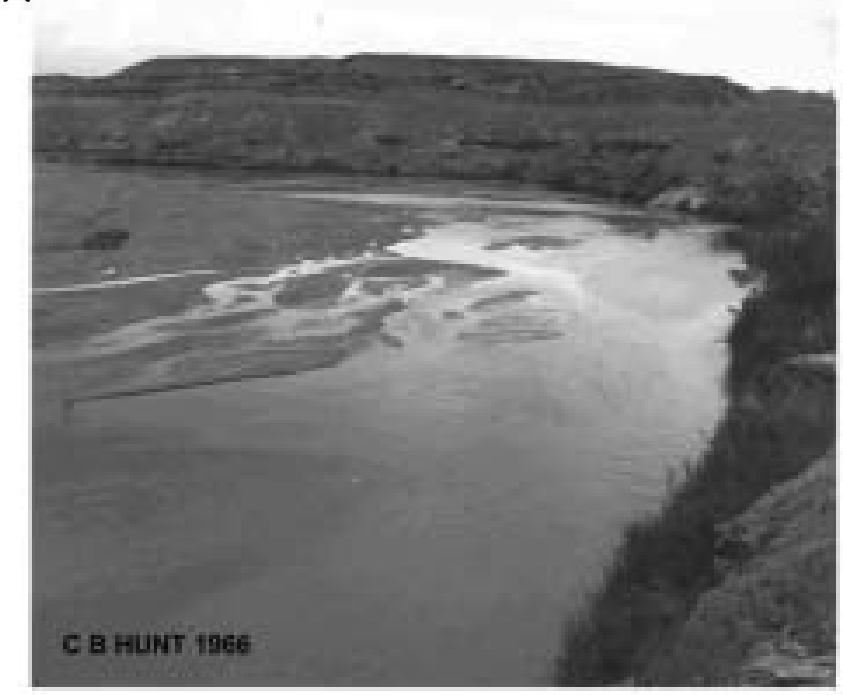

B

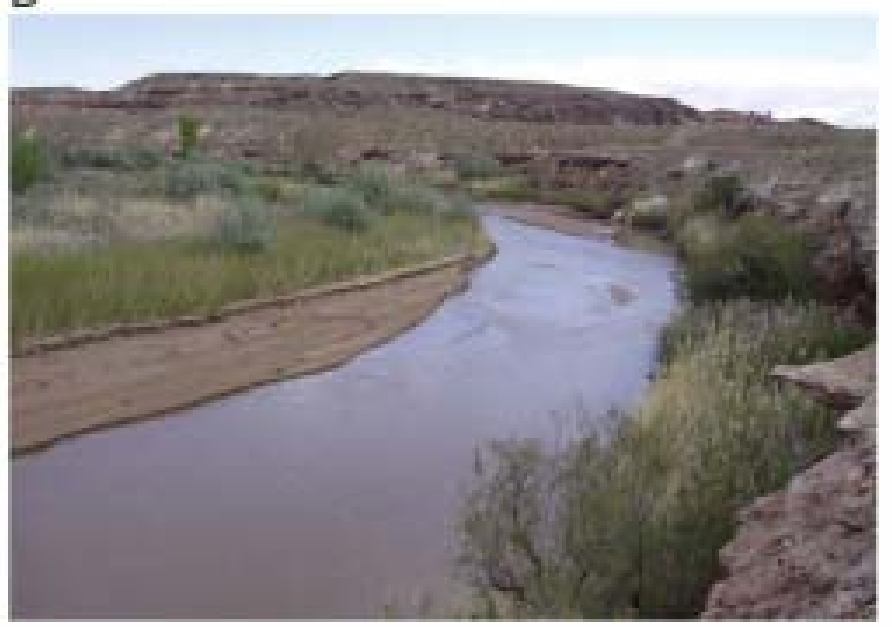

Fig. 13. Repeat photographs of the Fremont River in 1966 and 2005 to show channel shrinking over time. Location is five and a half kilometers west of Hanksville.

debris derived from adjacent buttes. Larger scattered fragments and broken nodules common on the pediment surface are derived from the slope above."

\subsection{Fremont River}

The average annual flow at the Fremont River stream gauge near Caineville, UT is $2.1 \mathrm{~m}^{3} / \mathrm{s}$. This gauge is located about $15 \mathrm{~km}$ upstream from the study area and has a contributing area of $3129 \mathrm{~km}^{2}$.

The Fremont River experienced a cycle of arroyo cutting and refilling common to many streams on the Colorado Plateau in the nineteenth century, and well described elsewhere (Gellis et al., 1991; Cook and Reeves, 1976). This part of the Fremont River valley was occupied by several farming communities by about 1875 . The river was described at that time as a shallow, meandering stream about $15 \mathrm{~m}$ wide. Water for irrigation was easily diverted with brush and rock dams. Then, beginning in 1897, a series of floods swept down the valley, creating a wide braided channel; repeatedly washing away fields, diversions, and irrigation canals; and causing the abandonment of many settlements. By 1937, this flood channel was about $300 \mathrm{~m}$ wide, with cut banks 3 to $4 \mathrm{~m}$ high (Fig. 12). In 1937, Hunt et al. (1953, p. 2073) estimated that some $30 \times 10^{6} \mathrm{~m}^{3}$ of material had been eroded from this reach of river, about $0.75 \times 10^{6} \mathrm{~m}^{3} / \mathrm{yr}$.

In the early 1940s, measurements of the Colorado River at Lee's Ferry showed that concentrations of both suspended load and dissolved solids had started to decrease (Gellis et al., 1991; Thomas 1963). At about this time, the arroyos of many of the Colorado Plateau rivers began to heal and revegetate (Hereford, 1986; Gellis et al., 1991). The channel of the Fremont River began to shrink and accrete sediment to a newly forming floodplain inset within the 1897 flood channel, at about this time, although records of the exact timing are sketchy. The rate of channel shrinking and sediment deposition increased after about 1980, until by 2000 the channel had been transformed into a narrow, meandering channel much as described a century earlier (Fig. 13).

By 2002, the channel in most locations had shrunk to a width of sufficiently small capacity that floods frequently went over bank and spread sediment over the entire floodplain (Fig. 14). Thus, channel evolution is apparently entering Everitt's stage II, aggradation (Everitt, 1993, p. 239, 1998, Fig. 3). A comparison of the computed magnitude and frequency curve for the Caineville gauge with recent floods that overtopped the banks and deposited sediment on the floodplain indicates that the 20-percent probability (five-year frequency) event is capable of building up the floodplain.

As the channel geometry evolves, the maximum stream power (in $\mathrm{W} / \mathrm{m}^{2}$ ) applied to the riverbed is decreasing, because flood waves are attenuated in the narrower and more sinuous channel, as described on the Gila River by Burkham (1976a). Moreover, increasingly dense riverbank and floodplain vegetation are increasing the roughness of the flow path, resulting in a larger percentage of total available energy consumed in turbulence and less in traction (Burkham, 1976b). Thus,

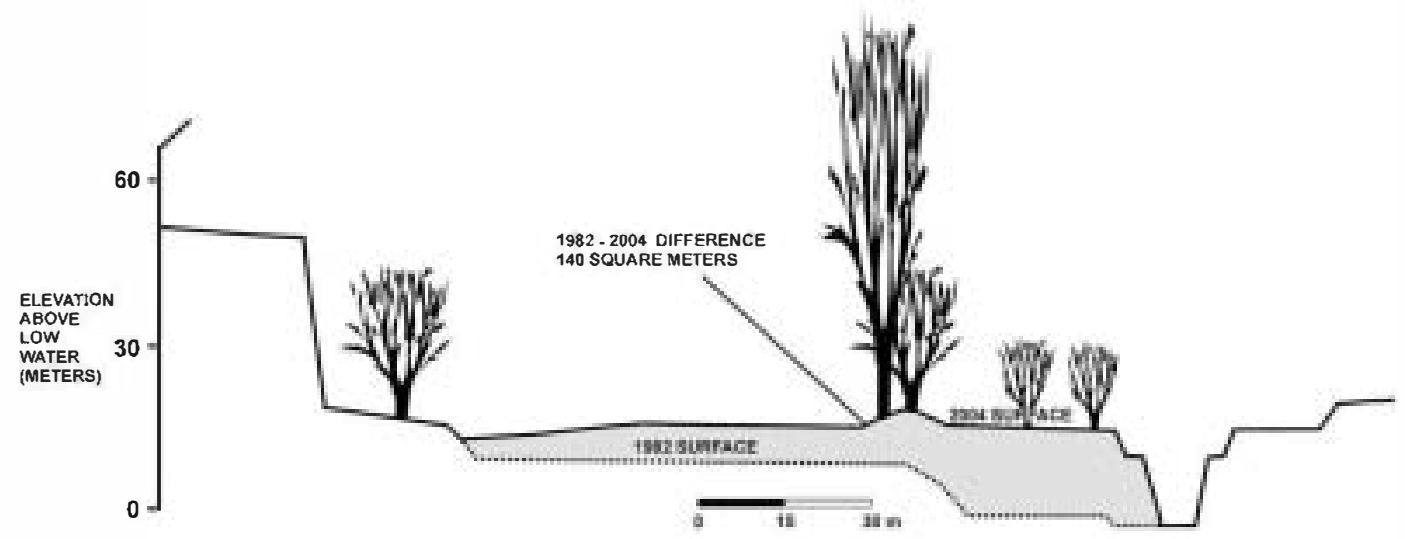

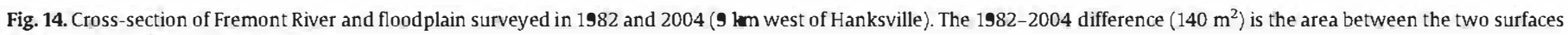
in the vertical plane of the drawing. 


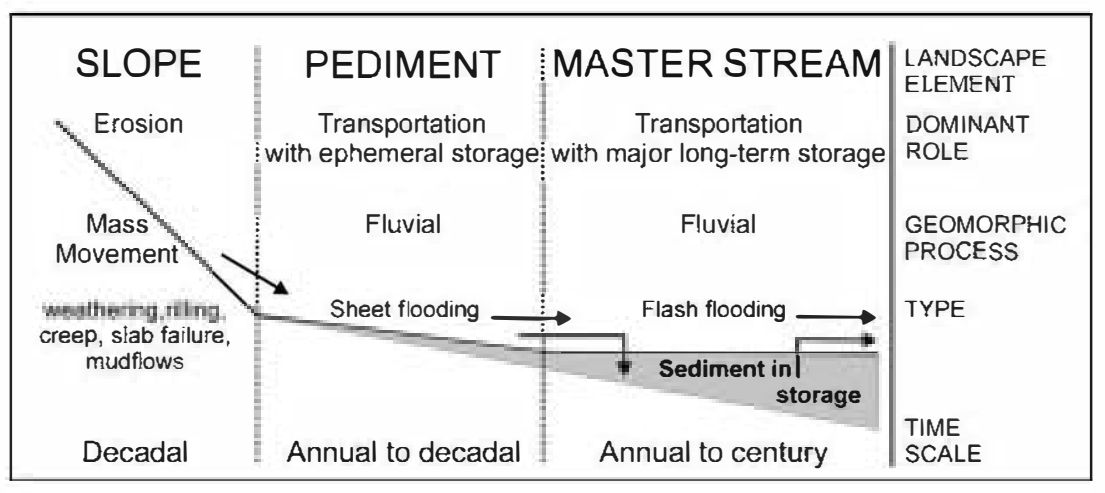

Fig. 15. System connections in the Mancos Shale badlands and Fremont River system.

an increasing proportion of sediment delivered from the upland landscape is being stored locally, and less is continuing downstream.

Fig. 14 shows one of two resurveyed cross sections of the river and part of its floodplain. The area between the 1982 and 2004 surfaces is $140 \mathrm{~m}^{2}$. Multiplying this figure by $1000 \mathrm{~m} / \mathrm{km}$ yields a floodplain sedimentation rate of $140,000 \mathrm{~m}^{3} / \mathrm{km}$ of valley. The average of the two cross-sections suggests roughly 4 million $\mathrm{m}^{3}$ of sediment storage in 20 years for the $40 \mathrm{~km}$ of valley, or $200,000 \mathrm{~m}^{3}$ per year. At that rate, It will take 200 years to restore the 30 million $\mathrm{m}^{3}$ of erosion reported by Hunt et al. (1953). Geologic and archaeologic data suggests that the previous cycle of arroyo filling on the Colorado Plateau took 400 years (Hereford, 1986, 2002) to 600 years (Graf, 1987, p. 266).

\section{Conclusions}

The elements that make up the Fremont River landscape, hillslope, pediment, and floodplain, are semi-independent actors in sediment delivery. Each operates with its own set of processes. In each landscape element, sediment movement is episodic at different frequencies, with intervals of storage between episodes of active transportation (Fig. 15). The system of slope to pediment and across the pediments is well-connected; the fluvial processes appear to have a shorter return interval than the mass-movement processes. However, the system of pediment to stream by way of the floodplain contains two components, and can be considered split-connectivity. The first component operates on the time scale of fluvial events and delivers sediment directly and indirectly to the stream. The second component operates on a multi-century time scale, and reflects the Fremont River's pattern of long periods of sediment storage punctuated by occasional episodes of erosion. Thus, the overall sense of a through-flowing stream of sediment from hillslope to base-level is apparent only on the millennial time scale.

On upland slopes, sediment moves primarily by mass-movement processes, including creep, slab failure, and mudflow. These processes are favored by winter's low-intensity, long-duration precipitation events that slake the shale, converting it to soil. Long-duration precipitation events, cool temperatures, and consequent low evaporation wet the crust and increase its weight. At least $65 \%$ of slope movement occurs in this season. Slab failures and mudflows appear to have a 20 to 30-year recurrence interval, while creep averages about $6 \mathrm{~cm}$ per year.

Sediment movement on pediments, alluvial flats, and low-order tributaries is dominated by fluvial processes. This occurs mainly during the summer monsoon season or early fall (the warm season of Hereford and Webb, 1992). These weather patterns produce highintensity, short-duration storm events that can produce sufficient runoff to transport sediment from the toe slopes to the Fremont River. About $95 \%$ of the sediment collected in the monitoring pits occurs during this time. These events are generally localized and appear to have about a 5 to 10 -year recurrence interval.
Seasonality of geomorphic processes within the Mancos Shale badlands is therefore evident, with annual variations in sediment generation, delivery and flushing, and resulting seasonal morphology (see, on this matter, Etheredge et al., 2004; Faulkner, 1988; Harvey, 1987; Schumm, 1956; Wells and Gutierrez, 1982).

On the mainstem Fremont River and higher-order tributaries, minor sediment movement is continuous; but on the grand scale of centuries, the system alternates between states of erosion (arroyo cutting) and deposition (arroyo healing). Sediment derived from both upland and upriver sources is currently being stored in $40 \mathrm{~km}$ of the Fremont River floodplain at the rate of $200,000 \mathrm{~m}^{3} / \mathrm{yr}$.

\section{Acknowledgements}

We would like to thank Brant Hallows, Tim Finger, and LaRell Chappell of the Richfield BLM office for their work with the sediment collection pits. Miguel Angel Sanz Santos drafted some of the figures. Richard Grauch of the USGS reviewed the text and made useful suggestions. The Universidad Complutense de Madrid provided library services and writing facilities. The Spanish Ministerio de Educacióny Ciencia research project CGL2006-07207 allowed completion of this work, and provided the framework for the initiation of analogous studies in the Segovia province of Spain. Our lead author, Andy Godfrey, unexpectedly passed away in August of 2006. We especially want to thank his widow Marie Godfrey for seeing us through our despair and helping us with last minute details.

\section{References}

Burkham, D.E., 1976a. Effects of changes in an alluvial channel on the timing, magnitude, and transformation of flood waves, southeastern Arizona. U.S. Geol. Surv. Prof. Pap. $655-\mathrm{K} 25 \mathrm{p}$.

Burkham, D.E., 1976b. Hydraulic effects of changes in bottom-land vegetation on three major floods, Gila River in southeastern Arizona. U.S. Geol. Surv. Prof. Pap. 655-J 14p.

Cook, R.U., Reeves, R.W., 1976. Arroyos and environmental change in the American Southwest. Clarendon, Oxford.

Dick, G.S., Anderson, R.S., Sampson, D.E., 1997. Control on flash flood magnitude and hydrograph shape, upper Blue Hills badlands, Utah. Geology 23 (1), 45-48.

Etheredge, D., Gutzler, D., Pazzaglia, F., 2004. Geomorphic response to seasonal variations in rainfall in the Southwest United States. GSA Bulletin, 116 (5-6), 606-618.

Everitt, B.L., 1993. Channel responses to declining flow on the Rio Grande between Ft. Quitman and Presidio, Texas. Geomorphology 6, 225-242.

Everitt, B.L, 1998. Chronology of the spread of tamarisk in the central Rio Grande Wetlands 18 (4), 658-668.

Faulkner, H., 1988. Gullyevolution in response to both snowmelt and flash flood erosion, western Colorado. In: Gardner, V. (Ed.), International Geomorphology 1986, vol 1 Wiley, Chichester, pp. 947-969.

Gellis, A., Hereford, R., Schumm, S.A., Hayes, B.R., 1991. Channel evolution and hydrologic variations in the Colorado River Basin: factors influencing sediment and salt loads. J. Hydrol. 124, 317-344.

Godfrey, A.E., 1979. Erosion rates on Mancos Shale Badlands, Wayne County, Utah. Geol Soc. Am. Abs. with Programs, Annual Meeting, vol. 11(7), p. 434.

Godfrey, A.E., 1997a. Wind erosion of Mancos Shale Badland Ridges by sudden drops in pressure. Earth Surf. Process. Landf. 22, 345-352. 
Godfrey, A.E., 1997b. Mass movement of Mancos Shale crust near Caineville, Utah: a 30 year record. Geogr. Ann. 79A (3), 185-194.

Goudie, A. (Ed.), 2004. Encyclopedia of Geomorphology. Routledge, London, p. 1156

Graf, W.L, 1987. Late Holocene sediment storage in canyons of the Colorado Plateau. GeoL Soc. Amer. Bull. 99, 261-271.

Harvey, A.M., 1987. Seasonality of processes on eroding gullies, a twelve year record of erosion rates. In: Goddard, A., Rapp, A. (Eds.), Processes et Mesure de l'érosion. CNRS, Paris, pp. 439-454.

Harvey, A.M., 1997. Coupling between hillslope gully systems and stream channels in the Howell Fells, Northwest England: temporal implications. Geomorphologie: Relief, Processes, Environnement 1, 3-20.

Harvey, A.M., 2001. Coupling between hillslopes and channels in upland fluvial systems: implications for landscape sensitivity, illustrated from the Howgill Fells, northwest England. Catena 42, 225-250.

Harvey, A.M., 2002. Effective timescales of coupling within fluvial systems. Geomorphology 44, 175-201.

Hepworth, R.C., 1965. Heaving in the subgrade of highways constructed on the Mancos Shale. Trans. Soc. Min. Eng. 232 (2), 24-141.

Hereford, R., 1986. Modern alluvial history of the Paria River drainage basin, southern Utah. Quat. Res. 25, 293-311.

Hereford, R., 2002. Valley-fill alluviation during the Little Ice Age (ca. A.D. 1400-1880), Paria River basin and southern Colorado Plateau, United States. GeoL Soc. Amer. Bull. 114 (12), 1550-1563.

Hereford, R., Webb, R.H., 1992. Historic variation in warm-season rainfall, southern Colorado Plateau, southwestern USA. Clim. Change 22, 239-256.

Hodges, W.K., Bryan, R.B., 1982. The influence of material behaviour on runoff initiation in the Dinosaur Badlands, Canada. In: Bryan, R., Yair, A. (Eds.), Badland Geomorphology and Piping. GeoBooks. (Geo Abstracts Ltd), Norwich, pp. 13-46.

Howard, A.D., 1994. Badlands. In: Abrahams, A.D., Parsons, A.J. (Eds.), Geomorphology of Desert Environments. Chapman and Hall, London, pp. 213-242.

Hunt, C.B., 1973. Thirty-year photographic record of a shale pediment, Henry Mountains, Utah. GeoL Soc. Amer. Bull. 2 (2), 689-695.
Hunt, C. B., Averitt, P., Miller, R.L, 1953. Geology and geography of the Henry Mountains region, Utah. U.S. GeoL Surv. Prof. Pap. 228234 p.

Patterson, C.G., Bromfield, C. S., Dubiel, R.F., Faulds, J.E., Larson, M.J., Milde, P.G., Peterson, F., 1985. Geologic map of the Mt. Ellen-Blue Hills Wilderness Study Area and Bull Mountain Study Area, Garfield and Wayne Counties, Utah. U.S. GeoL Surv. Map MF1756B.

Peterson, K.L, 1994. Modern and Pleistocene climate patterns in the West. In: Harper, K. T., Clair, L.L., St., Thorne, K.H., Hess, W.M. (Eds.), Natural History of the Colorado Plateau and Great Basin. University Press of Colorado, Boulder, CO, pp. 27-53.

Repka, J.L., Anderson, R.S., Dick, G.S., Finkel, R.C., 1997a. Dating the Fremont River Terraces. Part 7. In: Everitt, B.L, Godfrey, A.E., Anderson, R.S., Howard, A.D. (Eds.), Quaternary Geology and Geomorphology, Northern Henry Mountains Region. In: Link, P.K., Kowallis, B.J. (Eds.), Mesozoic to Recent Geology of Utah, Brigham Young University Geology Studies 42(II), 398-404.

Repka, J.L., Anderson, R.S., Finkel, R.C, 1997b. Cosmogenic dating of fluvial terraces, Fremont River, Utah. Earth Planet. Sci. Iett. 152, 59-73.

Schumm, S.A., 1956. Evolution of drainage systems and slopes in badlands at Perth Amboy, New Jersey. GeoL Soc. Amer. Bull., 67, 597-646.

Schumm, S.A., Lusby, G.C., 1963. Seasonal variations of infiltration capacity and runoff on hillslopes in western Colorado. J. Geophys. Res. 68, 3655-3666.

Smith, K.G., 1958. Erosional processes and landforms in Badlands National Monument, South Dakota. GeoL Soc. Amer. Bull. 69, 975-1007.

Stokes, W.L., 1986. Geology of Utah. University of Utah. Utah Museum of Natural History, Occasional paper No. 6, 280 p.

Thomas, H.E., 1963. Effects of drought in the Colorado River Basin. U.S. GeoL Surv. Prof. Pap. 372-F 51 p.

Wells, S.G., Gutierrez, A.A., 1982. Quaternary evolution of badlands in the southeastern Colorado Plateau, USA. In: Bryan, R.B., Yair, A. (Eds.), Badland Geomorphology and Piping. Geobooks, Norwich, pp. 239-258.0.

Western Regional Climate Center. Precipitation information is located on the web at: www.wrcc.dri.edu/cgi-bin/cliMAIN.pl?uthank. 